\title{
Why Special Issue of NJOG?
}

\section{Prof Dr Gehanath Baral ${ }^{1}$, Prof Dr Ganesh Dangal ${ }^{2}$}

Chief Editor, NJOG, ${ }^{2}$ Organizing Chairperson, ISOFS 2018

DOI: http://dx.doi.org/10.3126/njog.v13i2.21747

\section{ABSTRACT}

Additional issue is published on the occasion of ISOFS 2018 conference in Kathmandu. This is a unique practice this time in publication cycle because of the important women's health issue - the obstetric fistula.

Keywords: conference, fistula, iatrogenic, ISOFS, NESOG, obstetric

\section{INTRODUCTION}

Nepal Journal of Obstetrics and Gynecology (NJOG) is a professional society journal of Nepal Society of Obstetricians and Gynecologist (NESOG) that has been publishing since 2006 biannually in the month of June and December. It is an open access peer reviewed journal published with voluntary contribution from society members to take editorial task. There is no charge to submit, publish, read and download. It is published online in journal website (http://njog.org.np/njog/index.php/njog) and at the same time in Nepal Journals Online (https://www. nepjol.info/index.php/NJOG); and in a print form as well which is circulated free of charge to the members and health institutions.

\section{SPECIALTY}

ISOFS (International Society of Obstetric Fistula Surgeons) 2018 conference has been organized in
Kathmandu on 5th and 6th December with active contribution from NESOG as local organizer. This would be an opportunity to convey special scientific message related to obstetric fistula in scientific publication. Though the obstetric fistula is not a common health issue in Nepal, it is important to deal with for those women who do not have easy access to treatment; and the iatrogenic fistula is also not an uncommon entity. The scientific papers presented at this conference would be an asset for both societies - NESOG and ISOFS; that's why a special issue has emerged besides regular publication cycle.

\section{CONCLUSION}

Obstetric fistula has entered into the additional issue of NJOG first time in its publication cycle.

\section{CORRESPONDENCE}

Prof Dr Gehanath Baral

Organizing Secretary, ISOFS 2018, Local Organizing CommitteeNESOG, Kathmandu

Email: njogeditor@gmail.com; gehanath@gmail.com 